Supplement of Earth Syst. Dynam., 12, 121-132, 2021

https://doi.org/10.5194/esd-12-121-2021-supplement

(c) Author(s) 2021. This work is distributed under

the Creative Commons Attribution 4.0 License.

(c) (1)
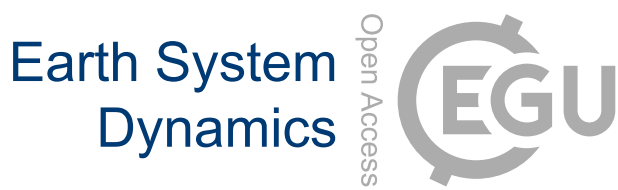

Supplement of

\title{
Synchronized spatial shifts of Hadley and Walker circulations
}

\section{Kyung-Sook Yun et al.}

Correspondence to: Kyung-Sook Yun (kssh@pusan.ac.kr)

The copyright of individual parts of the supplement might differ from the CC BY 4.0 License. 


\section{Strength mode for $\mathrm{WC}$ and $\mathrm{HC}$}

The first EOF of WC variability (i.e., WC1) and the second EOF mode of HC variability (i.e., HC2) represent canonical E1 Niño driven WC and HC variability (Supplementary Fig. S1) (e.g., Bayr et al. 2014): an anomalous clockwise cell over the eastern Indian Ocean and an anomalous anticlockwise cell over the western central Pacific, accompanied by an anomalous descending motion over the Maritime continent (MC; centered at $\left.\sim 130^{\circ} \mathrm{E}\right)$ and an eastward shift of ascending branch toward the central Pacific compared to the climatological circulation pattern (Supplementary Fig. S1a); the equatorially symmetric HC cells and an enhanced upward motion in the equatorial region (Supplementary Fig. S1b). To focus on the El Niño-related circulation pattern, the WC1 EOF mode is reversed in sign so that positive values refer to a weakening of the $\mathrm{WC}$ and strengthening of the HC. Although the WC shows a mixed feature of strength and spatial shift, Supplementary Table S1 clearly reveals the statistically significant connection between WC1-HC2 and the strength of the anomalous circulations (e.g., interannual correlation coefficient $\mathrm{CC}$ between the WC variability and WC strength index $\sim 0.84$; CC between the HC variability and HC strength index $\sim 0.82)$. This suggests that the ENSO-driven WC and HC variability is primarily associated with the co-varying strength of WC and HC (i.e., an weakening of WC and strengthening of $\mathrm{HC}$ ).

\section{Definition of indices for WC and HC}

To measure the strength variations and spatial shifts of both the Walker circulation (WC) and Hadley circulation (HC) ascending branches, we define several indices as follows: (1) the InterTropical Convergence Zone (ITCZ) position was calculated by zonal averaged latitudinal position of the ITCZ that is identified as the maximum in time-mean precipitation; (2) the ITCZ intensity is defined as zonal averaged rainfall of the ITCZ (latitudinal position defined by (1)); (3) Rainfall intensity over the MC (Rain_MC) are the area-averaged precipitation anomalies over $\left[10^{\circ} \mathrm{S}-10^{\circ} \mathrm{N}\right.$, $\left.100^{\circ} \mathrm{E}-130^{\circ} \mathrm{E}\right]$; (4) Rainfall intensity over the western North Pacific (WNP, Rain_WNP) are the areaaveraged precipitation anomalies over $\left[0^{\circ}-15^{\circ} \mathrm{N}, 140^{\circ} \mathrm{E}-170^{\circ} \mathrm{E}\right]$; (5) $\mathrm{ITCZ}$ position over the $\mathrm{MC}$ is 
the latitudinal position of the ITCZ zonally averaged over the MC [100-130E]; (6) WCS (Walker circulation strength) and (7) HCS (Hadley circulation strength) are respectively measured by (6) the maximum value of tropical mean $\left[5^{\circ} \mathrm{S}-5^{\circ} \mathrm{N}\right]$ mass stream function $(\mathrm{MSF})$ at $500 \mathrm{hPa}(500 \mathrm{MSF})$ and by (7) the maximum of zonal mean 500MSF within the latitudinal zone of $30^{\circ} \mathrm{S}-30^{\circ} \mathrm{N}$ (Oort and Yienger 1996); (8) WCDS (Walker circulation dipole strength) and (9) HCDS (Hadley circulation dipole strength) are respectively defined as (8) the difference in area-averaged tropical mean 500MSF between the central-eastern Pacific $\left[160^{\circ} \mathrm{E}-120^{\circ} \mathrm{W}\right]$ and the Indo-western Pacific $\left[60^{\circ} \mathrm{E}-140^{\circ} \mathrm{E}\right]$ and as (9) the difference in area-averaged zonal mean 500MSF between Northern hemisphere $\left[\mathrm{NH} ; 5^{\circ} \mathrm{N}\right.$ $25^{\circ} \mathrm{N}$ ] and Southern hemisphere [SH; $25^{\circ} \mathrm{S}-5^{\circ} \mathrm{S}$ ] (Ma and Yu 2014; Xie and Zhou 2017). The interannual correlation coefficients between indices and $\mathrm{WC} / \mathrm{HC} \mathrm{PC}$ variability are presented in Supplementary Table S1. These indices were used only in Supplementary Information. 


\section{Supplementary Tables and Figures}

Supplementary Table S1 | Absolute correlation coefficients between inter-annual variabilities of Walker/Hadley circulations and climate indices in terms of both strength and spatial shifts. The detail for climate indices was explained in Supplementary text. The statistically significant corrections at the $95 \%$ confidence level are denoted in bold type.

\begin{tabular}{|c|c|c|c|c|}
\hline \multirow{2}{*}{$\begin{array}{c}\text { Correlation } \\
\text { coefficient }\end{array}$} & \multicolumn{2}{|c|}{ Strength mode } & \multicolumn{2}{c|}{ Shift Mode } \\
\cline { 2 - 5 } & Walker mode (WC1) & Hadley mode (HC2) & Walker mode (WC2) & Hadley (HC1) mode \\
\hline ITCZ position & 0.25 & 0.34 & 0.28 & $\mathbf{0 . 5 4}$ \\
\hline ITCZ intensity & $\mathbf{0 . 5 2}$ & $\mathbf{0 . 5 7}$ & 0.23 & 0.15 \\
\hline $\begin{array}{c}\text { Rainfall intensity } \\
\text { over MC }\end{array}$ & $\mathbf{0 . 7 7}$ & $\mathbf{0 . 5 3}$ & 0.01 & 0.12 \\
\hline $\begin{array}{c}\text { Rainfall intensify } \\
\text { over } \text { WNP }\end{array}$ & 0.02 & 0.09 & $\mathbf{0 . 9 1}$ & $\mathbf{0 . 6 3}$ \\
\hline $\begin{array}{c}\text { ITCZ position } \\
\text { over } M C\end{array}$ & 0.06 & 0.18 & $\mathbf{0 . 5 2}$ & $\mathbf{0 . 5 5}$ \\
\hline $\begin{array}{c}\text { WC strength } \\
\text { WCDS }\end{array}$ & $\mathbf{0 . 8 4}$ & $\mathbf{0 . 6 7}$ & 0.08 & 0.05 \\
\hline HC strength & $\mathbf{0 . 6 3}$ & $\mathbf{0 . 7 8}$ & 0.44 & 0.36 \\
\hline HCDS & $\mathbf{0 . 6 0}$ & $\mathbf{0 . 8 2}$ & 0.13 & 0.02 \\
\hline
\end{tabular}


Supplementary Table S2 | Description of 19 AMIP models as part of CMIP5 used in this study. The $\mathrm{CC}$ indicates the inter-annual correlation coefficient between PC time series of WC2 and HC1 during 1979-2008. The strong PSYN models are denoted in bold ${ }^{* *}$, while the weak PSYN models are presented in bold ${ }^{++}$.

\begin{tabular}{|c|c|c|c|}
\hline \# & Model & Institution & CC (WC2, HC1) \\
\hline 1 & ACCESS1.0 & CSIRO-BOM, Australia & $0.70 * *$ \\
\hline 2 & BNU-ESM & $\begin{array}{l}\text { College of Global Change and Earth System Science, } \\
\text { China }\end{array}$ & 0.57 \\
\hline 3 & СМСC-CM & $\begin{array}{l}\text { Centro Euro-Mediterraneo per I Cambiamenti } \\
\qquad \text { Climatici, Italy }\end{array}$ & 0.55 \\
\hline 4 & CNRM-CM5 & $\begin{array}{c}\text { Centre National de Recherches Météorologiques (CNRM) } \\
\text { and Centre Europeen de Recherches et de For- mation } \\
\text { Avancee en Calcul Scientifique (CERFACS), France }\end{array}$ & $0.67 * *$ \\
\hline 5 & CSIRO-Mk3.6.0 & CSIRO-QCCCE, Australia & 0.56 \\
\hline 6 & CanAM4 & $\begin{array}{l}\text { Canadian Centre for Climate Modelling and } \\
\text { Analysis, Canada }\end{array}$ & 0.54 \\
\hline 7 & GFDL-CM3 & $\begin{array}{l}\text { NOAA Geophysical Fluid Dynamics Laboratory, } \\
\text { USA }\end{array}$ & 0.48 \\
\hline 8 & $\begin{array}{l}\text { GFDL-HIRAM- } \\
\text { C180 }\end{array}$ & $\begin{array}{l}\text { NOAA Geophysical Fluid Dynamics Laboratory, } \\
\text { USA }\end{array}$ & 0.47 \\
\hline 9 & GISS-E2-R & NASA Goddard Institute for Space Studies, USA & 0.51 \\
\hline $\begin{array}{l}1 \\
0\end{array}$ & HadGEM2-A & Met Office Hadley Centre, UK & $0.72 * *$ \\
\hline 1 & IPSL-CM5A-LR & Institut Pierre-Simon Laplace, France & 0.56 \\
\hline $\begin{array}{l}1 \\
2\end{array}$ & MIROC5 & MIROC, Japan & 0.52 \\
\hline $\begin{array}{l}1 \\
3\end{array}$ & MPI-ESM-LR & Max-Planck-Institut für Meteorologie, Germany & 0.66 \\
\hline
\end{tabular}




\begin{tabular}{|l|c|c|c|}
\hline $\mathbf{1}$ & MPI-ESM-MR & Max-Planck-Institut für Meteorologie, Germany & 0.63 \\
\hline $\mathbf{1}$ & MRI-CGCM3 & Meteorological Research Institute, Japan & $\mathbf{0 . 6 9}^{* *}$ \\
\hline $\mathbf{1}$ & MRI-AGCM3- & Meteorological Research Institute, Japan & $\mathbf{0 . 3}^{++}$ \\
$\mathbf{6}$ & $\mathbf{2 H}$ & Norwegian Climate Centre, Norway & $\mathbf{0 . 4 2}^{++}$ \\
\hline $\mathbf{1}$ & NorESM1-M & & $\mathbf{0 . 3 2}^{++}$ \\
$\mathbf{7}$ & $\mathbf{1}$ & BCC-CSM1.1(m) & Beijing Climate Center, China \\
\hline $\mathbf{8}$ & & & \\
\hline $\mathbf{1}$ & INM-CM4 & Institute for Numerical Mathematics, Russia & $\mathbf{0 . 4}^{++}$ \\
\hline
\end{tabular}

Supplementary Table S3 | Description of 21 AMIP models as part of the CMIP6 used in this study. The CC indicates the inter-annual correlation coefficient between PC time series of WC2 and HC1 during 1979-2014. The strong SYN models are denoted in bold ${ }^{* *}$, while the weak SYN models are presented in bold ${ }^{++}$.

\begin{tabular}{|c|c|c|c|}
\hline \# & Model & Institution & $\mathrm{CC}(\mathrm{WC} 2, \mathrm{HC} 1)$ \\
\hline 1 & BCC-CSM2-MR & Beijing Climate Center, China & 0.47 \\
\hline 2 & BCC-ESM1 & Beijing Climate Center, China & $\mathbf{0 . 3 3}^{++}$ \\
\hline 3 & CAMS-CSM1-0 & $\begin{array}{l}\text { Chinese Academy of Meteorological Sciences, } \\
\text { China }\end{array}$ & 0.47 \\
\hline 4 & CESM2-WACCM & $\begin{array}{l}\text { National Center for Atmospheric Research, } \\
\text { Climate and Global Dynamics Laboratory, USA }\end{array}$ & 0.54 \\
\hline 5 & CESM2 & $\begin{array}{l}\text { National Center for Atmospheric Research, } \\
\text { Climate and Global Dynamics Laboratory, USA }\end{array}$ & 0.45 \\
\hline 6 & CanESM5 & $\begin{array}{l}\text { Canadian Centre for Climate Modelling and } \\
\text { Analysis, Canada }\end{array}$ & 0.56 \\
\hline 7 & ES3M-1-0 & E3SM-Project, USA & $0.66 * *$ \\
\hline 8 & EC-Earth3-Veg & EC-Earth-Consortium, & 0.41 \\
\hline 9 & FGOALS-f3-L & Chinese Academy of Sciences, China & 0.57 \\
\hline
\end{tabular}




\begin{tabular}{|c|c|c|c|}
\hline $\mathbf{0}$ & GFDL-AM4 & $\begin{array}{l}\text { NOAA Geophysical Fluid Dynamics Laboratory, } \\
\text { USA }\end{array}$ & 0.50 \\
\hline 1 & GFDL-CM4 & $\begin{array}{l}\text { NOAA Geophysical Fluid Dynamics Laboratory, } \\
\text { USA }\end{array}$ & $0.59 * *$ \\
\hline 2 & GISS-E2-1-G & NASA Goddard Institute for Space Studies, USA & 0.34 \\
\hline 1 & IPSL-CM6A-LR & Institut Pierre-Simon Laplace, France & $0.3^{++}$ \\
\hline $\begin{array}{l}1 \\
4\end{array}$ & MIROC6 & MIROC, Japan & 0.48 \\
\hline 5 & MRI-ESM2-0 & Meteorological Research Institute, Japan & 0.39 \\
\hline 6 & NESM3 & $\begin{array}{l}\text { Nanjing University of Information Science and } \\
\text { Technology, China }\end{array}$ & 0.35 \\
\hline 1 & SAM0-UNICON & Seoul National University, Republic of Korea & 0.54 \\
\hline 8 & CNRM-CM6-1 & $\begin{array}{c}\text { Centre National de Recherches Météorologiques (CNRM) } \\
\text { and Centre Europeen de Recherches et de For- mation } \\
\text { Avancee en Calcul Scientifique (CERFACS), France }\end{array}$ & $0.19^{++}$ \\
\hline 9 & CNRM-ESM2-1 & CNRM-CERFACS, France & $\mathbf{0 . 0 8}^{++}$ \\
\hline 0 & $\begin{array}{c}\text { HadGEM3-GC31- } \\
\text { LL }\end{array}$ & Met Office Hadley Centre, UK & $0.64 * *$ \\
\hline 1 & UKESM1-0-LL & Met Office Hadley Centre, UK & $0.58 * *$ \\
\hline
\end{tabular}


(a) EOF 1, Walker strength mode, ERAI (35.78\%)

(b) EOF 2, Hadley strength mode, ERAI (17.70\%)
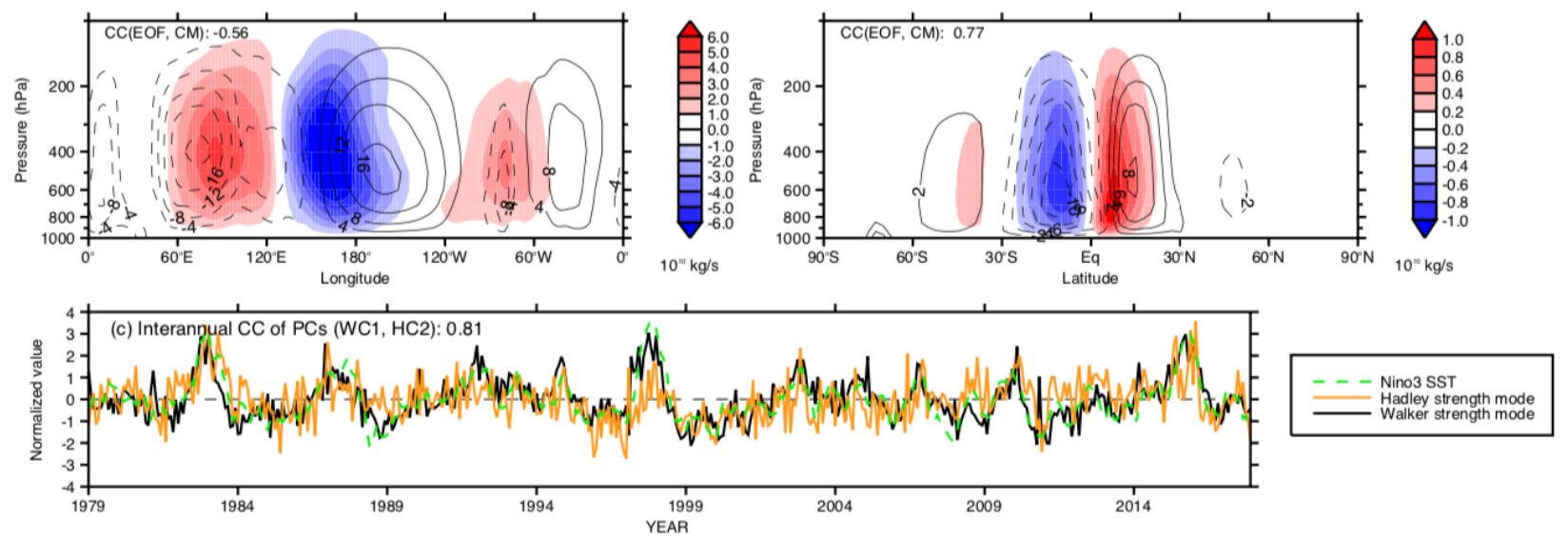

Supplementary Figure S1 | Dominant pattern of the strength modes of the Walker and Hadley circulations. (a-b) The loading patterns of the strength modes (i.e., mode 1 for Walker and mode 2 for Hadley; denoted by shading) for (a) Walker circulation (WC) and (b) Hadley circulation (HC) variability. The $\mathrm{WC}$ and $\mathrm{HC}$ are identified as (a) tropical $\left(5^{\circ} \mathrm{S}-5^{\circ} \mathrm{N}\right)$ averaged mass stream function (MSF) anomalies and (b) zonally averaged MSF anomalies, obtained from the monthly ERA interim (ERAI) data during the period 1979-2017. The contours show the climatological mean of the MSF for the circulations. (c) Normalized time series: The corresponding principal components (PCs) of the strength modes (i.e., Walker 1 mode and Hadley 2 mode; WC1 \& HC2) and Niño3 SST anomaly (green dashed line). The inter-annual correlation coefficient (CC) is $\sim 0.91$ for WC1-Niño3; $\sim 0.87$ for HC2-Niño3; 0.81 between $\mathrm{WC1}$ and $\mathrm{HC} 2$. 
(a) Interannual relationship of PCs, 19 AMIP5

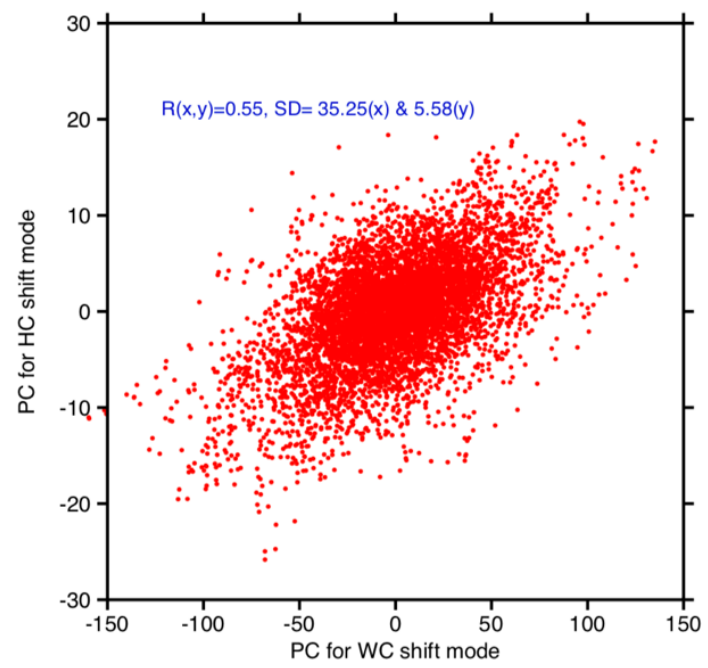

(c) Interannual relationship of PCs, 21 AMIP6

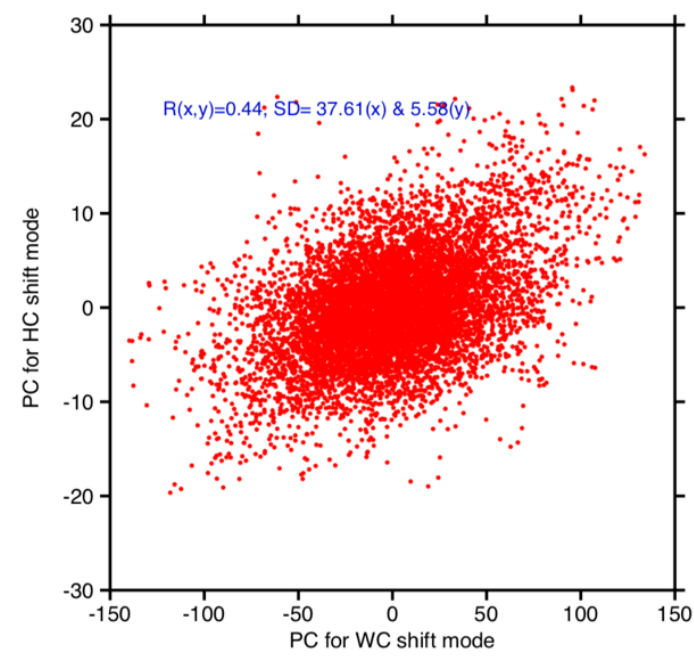

(b) Interannual relationship of PCs, 19 AMIP5 depature from MME

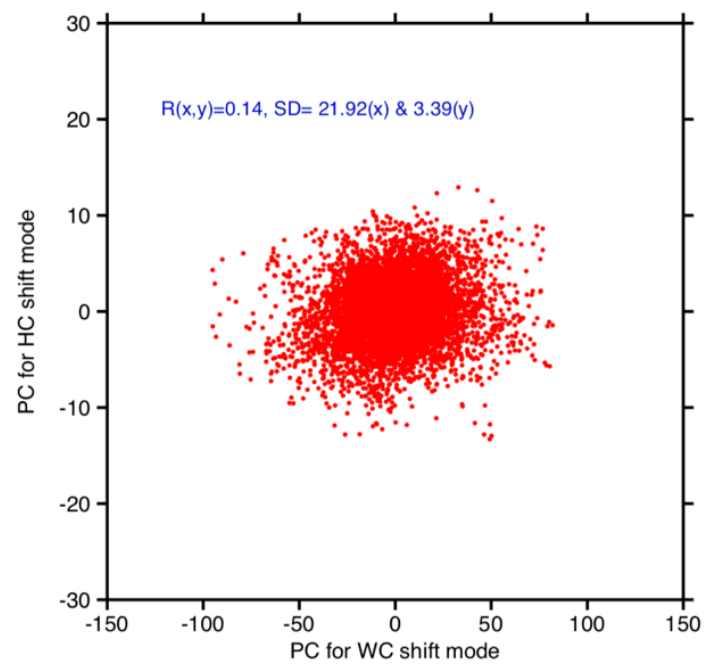

(d) Interannual relationship of PCs, 21 AMIP6 depature from MME

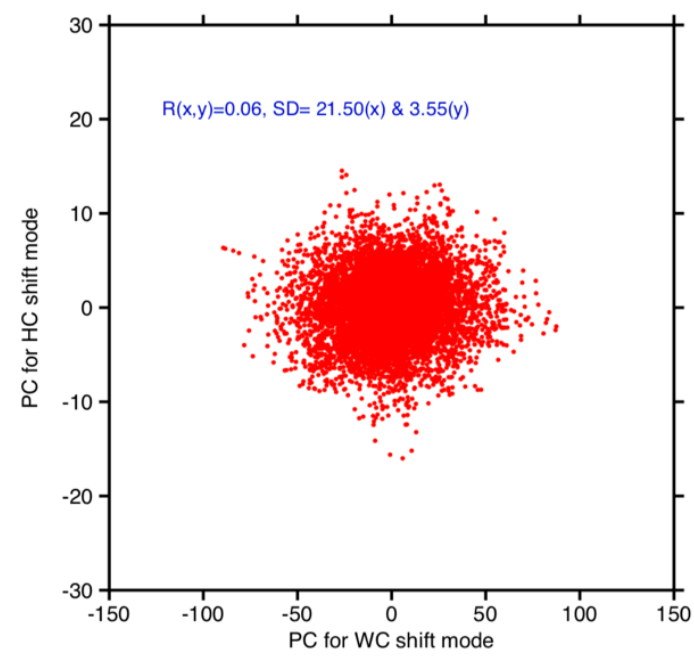

Supplementary Figure S2 | Interannual relationship between shift modes in the AMIP simulations. (a-b) Scatter plot of WC shift mode (WC2) versus HC shift mode (HC1), based on the PC time series using (a) the individual 19 AMIP5 simulations and (b) the departure from the multimodel mean (MME). (c-d) Same as (a-b), but for 21 AMIP6 simulations. 


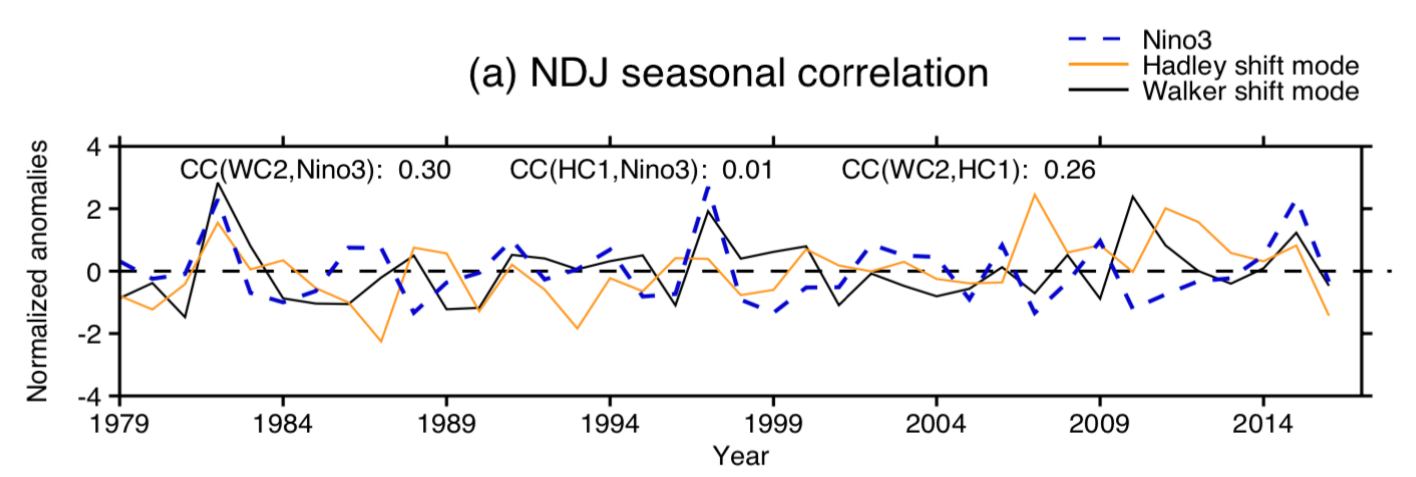

(b) FMA seasonal correlation

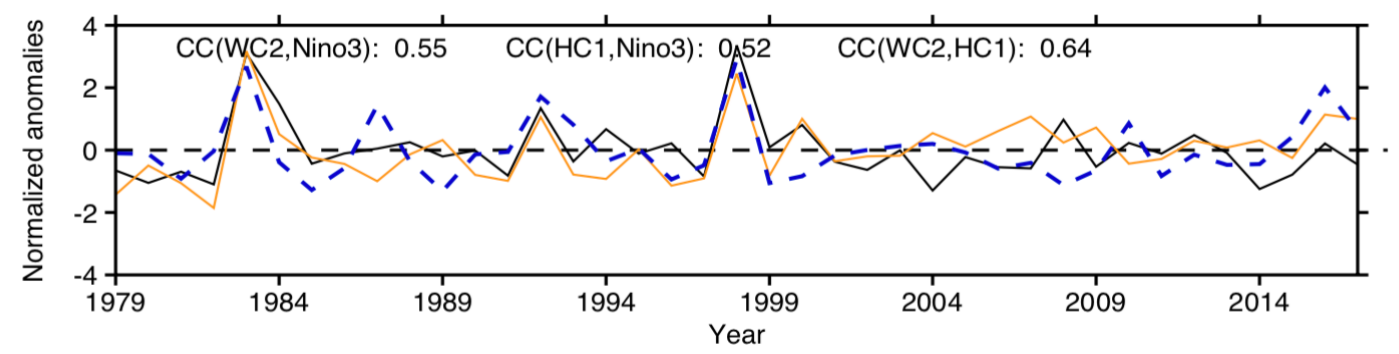

(c) MJJ seasonal correlation

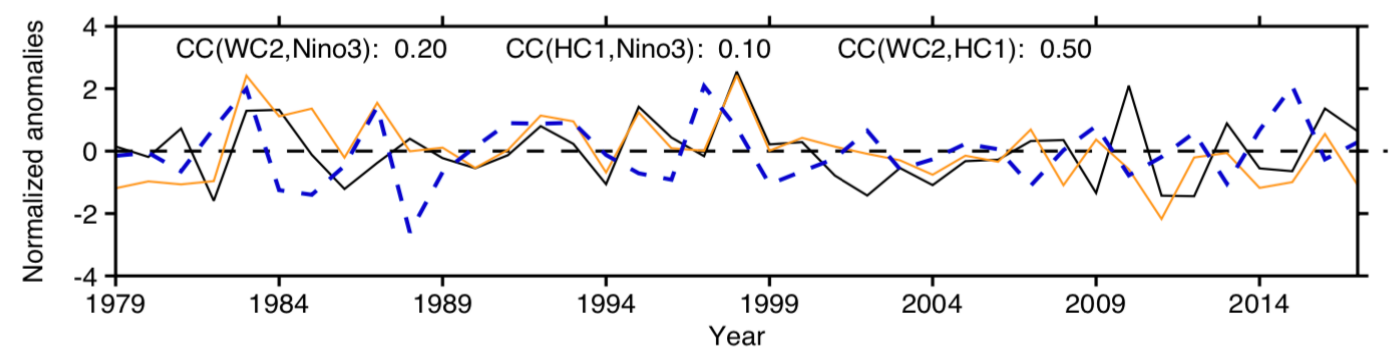

(d) ASO seasonal correlation

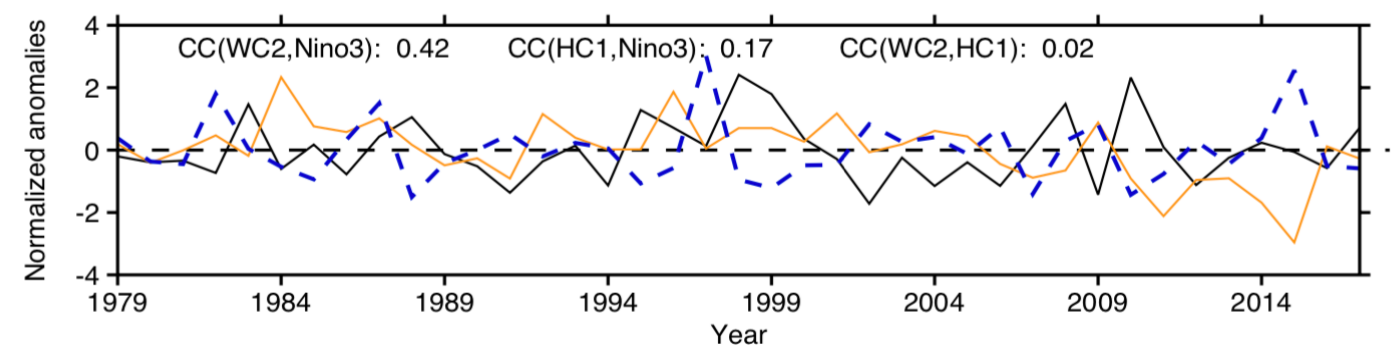

Supplementary Figure S3 | Seasonal relationship between the WC-HC shift modes and Niño3. Seasonal mean normalized time series of Niño3 SST anomaly (blue) and the PCs of WC2 (black) HC1 (yellow) mode: (a) November-December-January (NDJ), (b) February-March-April (FMA), (c) May-June-July (MJJ), and (d) August-September-October (ASO). 


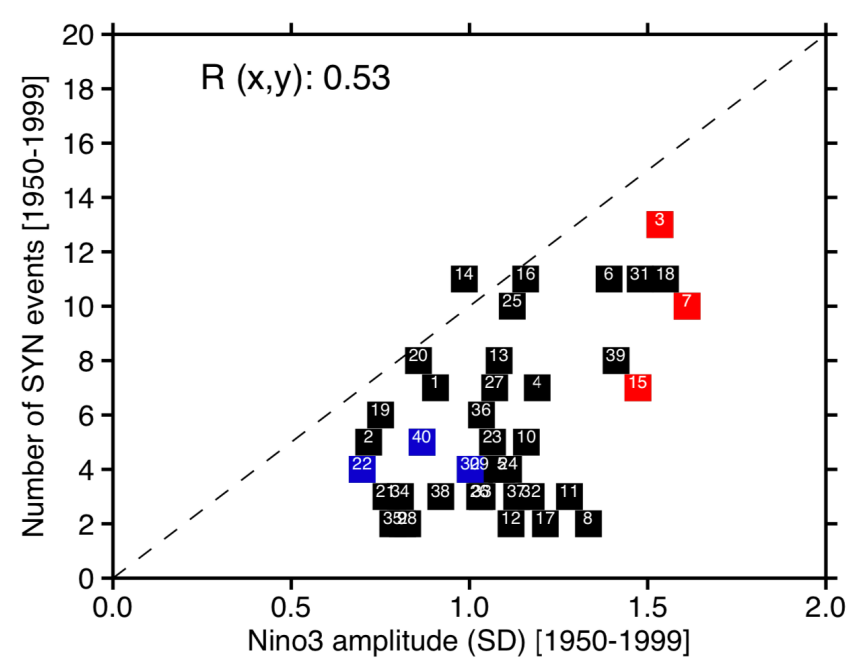

\begin{tabular}{|c|c|c|c|c|c|c|c|}
\hline 1:ACCESS1-0 & 2:ACCESS1-3 & 3:BNU-ESM & 4:CCSM4 & 5:CESM1-BGC & 6:CESM1-CAM5 & 7:CESM1-CAM5-1-FV2 & 8:CMCC-CESM \\
\hline 9:СMCC-CM & 10:CMCC-CMS & 11:CNRM-CM5 & 12:CSIRO-Mk3-6-0 & 13:CanESM2 & 14:FGOALS-g2 & 15:FIO-ESM & 16:GFDL-CM3 \\
\hline 17:GFDL-ESM2G & 18:GFDL-ESM2M & 19:GISS-E2-H & 20:GISS-E2-H-CC & 21:GISS-E2-R & 22:GISS-E2-R-CC & 23:HadGEM2-AO & 24:HadGEM2-CC \\
\hline 25:HadGEM2-ES & 26:IPSL-CM5A-LR & 27:IPSL-CM5A-MR & 28:IPSL-CM5B-LR & 29:MIROC-ESM & 30:MIROC-ESM-CHEM & 31:MIROC5 & 32:MPI-ESM-LR \\
\hline 33:MPI-ESM-MR & 34:MRI-CGCM3 & 35:MRI-ESM1 & 36:NorESM1-M & 37:NorESM1-ME & 38:bcc-csm1-1 & $39:$ bcc-csm1-1-m & 40:inmcm4 \\
\hline
\end{tabular}

Supplementary Figure S4 | WC-HC synchronization and ENSO amplitude in CMIP5 models. Scatter plot of the present-day (1950-1999) Niño3 SST standard deviation (SD) versus the presentday number of PSYN events, based on the historical simulation of the 40 CMIP5 models. The PSYN events are determined as a long-lasting phase synchronized event exceeding 6 months duration. The CMIP5 models show the PSYN event of $\sim 5.7 \pm 3.2 \mathrm{SD}$. The S3MMM group is indicated by red color and the W3MMM group by blue color. Here, S3MMM are the models that have a Niño3 SST anomaly standard deviation greater than 1.0 and high correlation between shift modes exceeding a value of 0.49, while W3MMM are models with Niño3 SST anomaly standard deviation less than 0.5. 
(a) Monthly variability, OBS

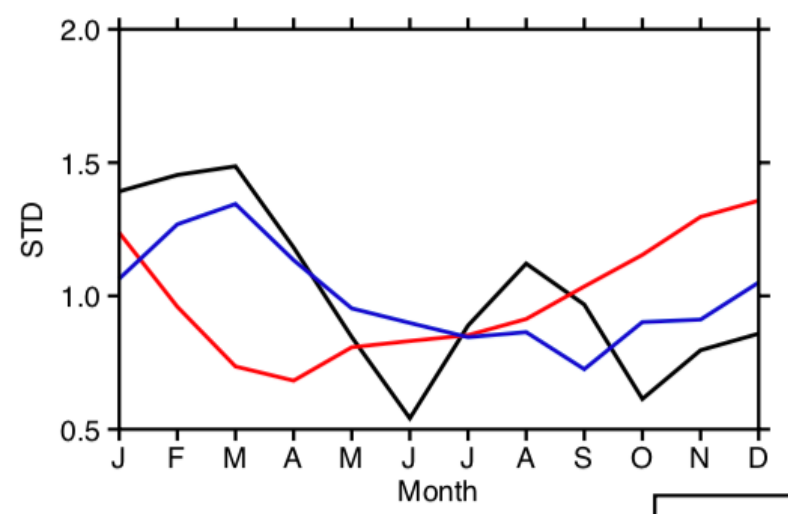

(b) Monthly variability, AMIP MME

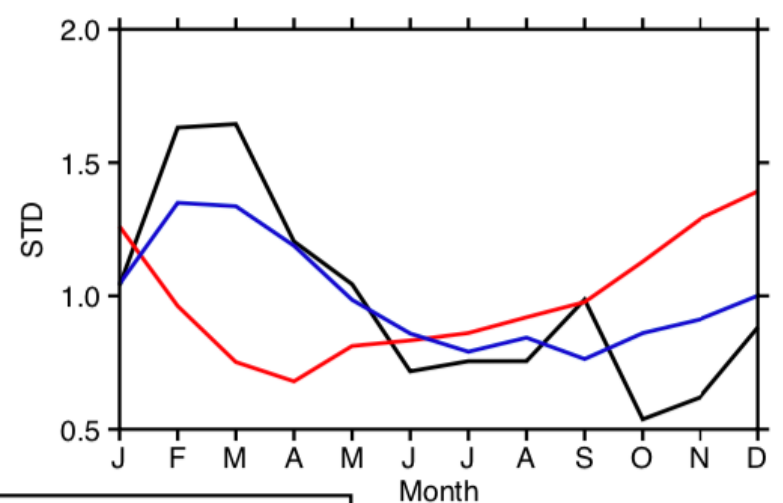

$\Delta$ SST(SIO,WNP)

Nino3

Co-variability (WC2 x HC1)

Supplementary Figure S5 | Annual cycle of WC-HC co-variability in the observations and AMIP MME. Monthly variability standard deviation of Niño3 (red), SSTgrad (blue), and WC-HC co-variability (black; product of WC2 and HC1 PCs), obtained from observations and the AMIP MME. 
(a) VP850 [OBS]

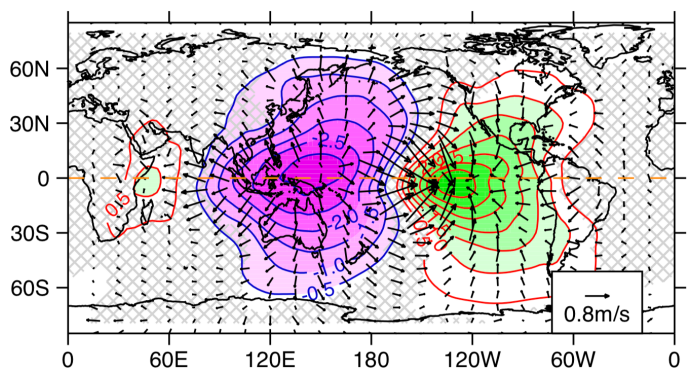

(c) PRCP/wind850 [OBS]

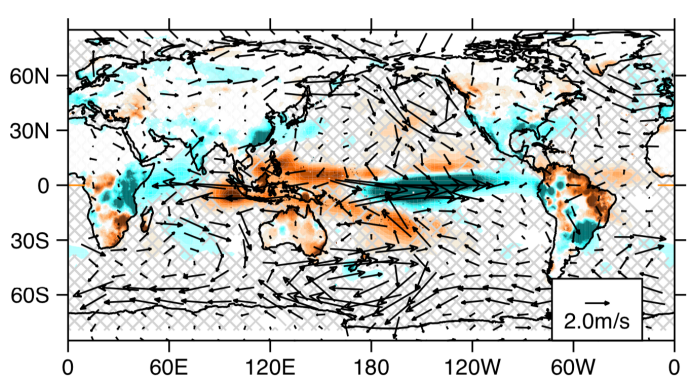

(b) VP850 [AMIP_MME]

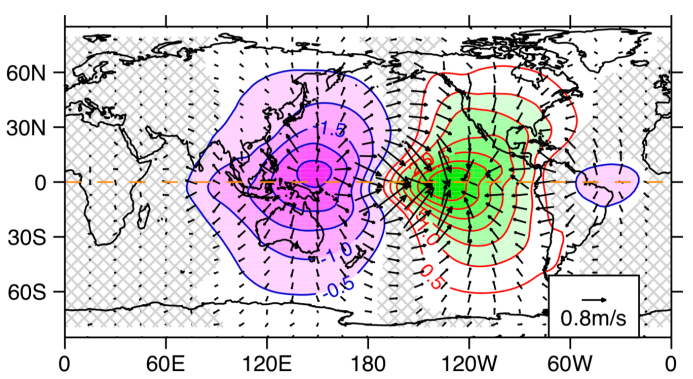

(d) PRCP/wind850 [AMIP_MME]

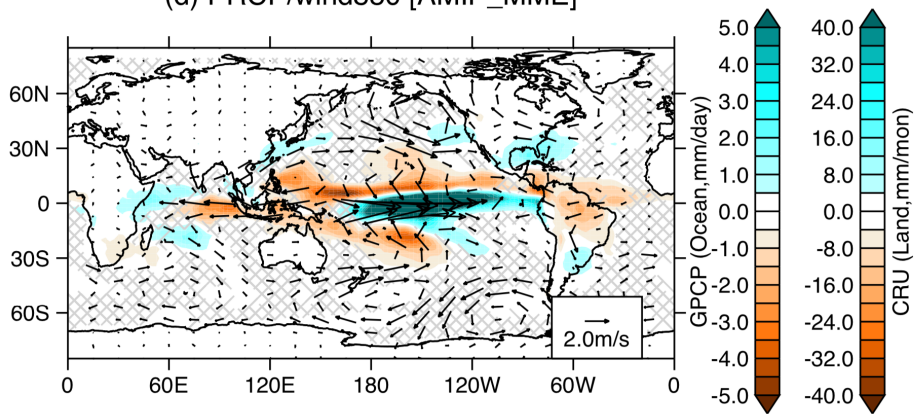

Supplementary Figure S6 | Global pattern of phase synchronized shifts during El Niño conditions. Composite anomaly of PSYN months (i.e., the absolute tendency of phase difference is less than 0.3) with November-December[0]-January[1] El Ninos (Niño3 > 1.5SD), obtained from the observations (left column) and the AMIP MME (right column): (a, b) SST (shading) and 850hPa stream function anomaly; (c, d) $850 \mathrm{hPa}$ velocity potential (VP850) anomaly; (e-f) precipitation (GPCP for ocean and CRU for land; shading) and $850 \mathrm{hPa}$ wind (vector) anomaly. The hatching indicates differences that are statistically insignificant at the $95 \%$ confidence level. 
(a) VP850 [OBS]

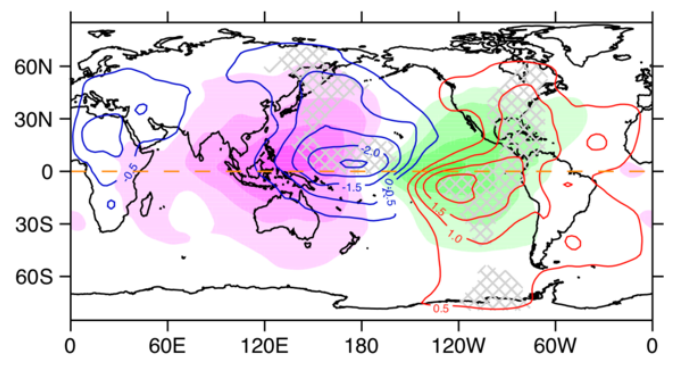

(c) PRCP [OBS]

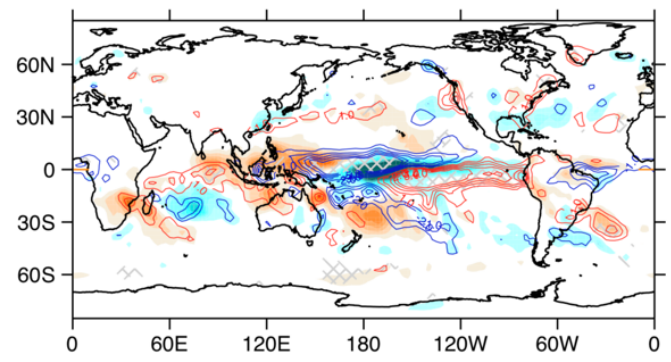

(b) VP850 [AMIP_MME]

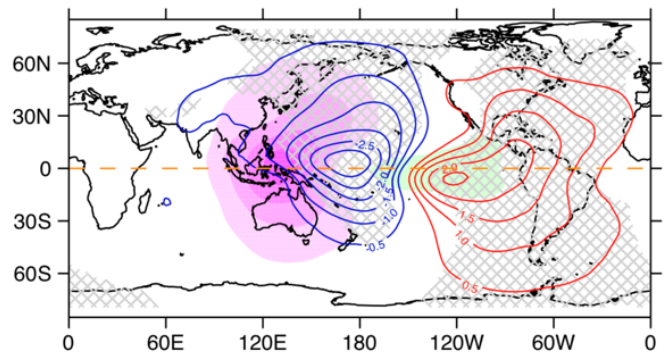

(d) PRCP [AMIP_MME]

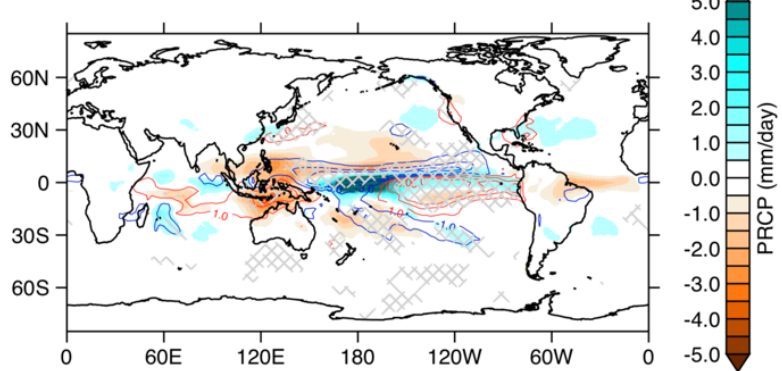

Supplementary Figure S7 | Comparison between phase synchronized and non- synchronized ENSO events. Composite anomalies (shading) during non-PSYN months (i.e., the absolute tendency of phase difference is greater than 0.3) with February-March-April (FMA[1]) El Niño (FMA[1] Niño3 $>0.5 \mathrm{SD}$ ) and the difference between non-PSYN months and PSYN months (contours), obtained from the observations (left column) and the AMIP MME (right column): (a, b) $850 \mathrm{hPa}$ velocity potential (VP850) and (c-d) precipitation anomaly. The hatching shows the area where the difference is statistically significant at the $99 \%$ confidence level. 
(a) SST [S3MMM]

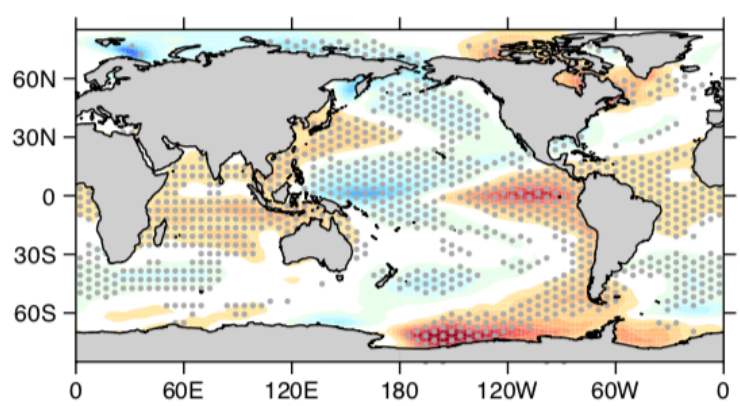

(c) PRCP [S3MMM]

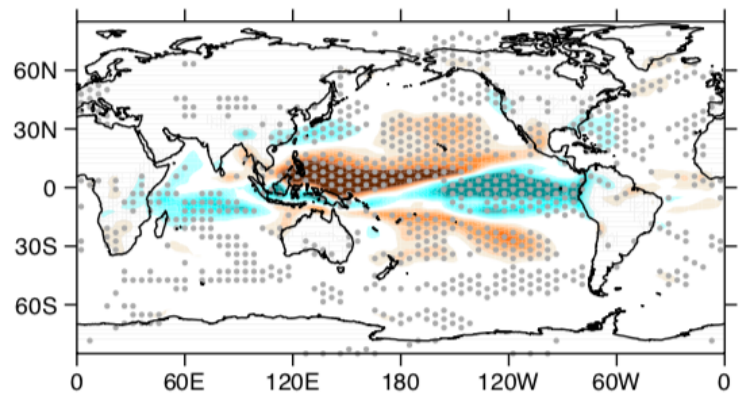

(b) SST [W3MMM]

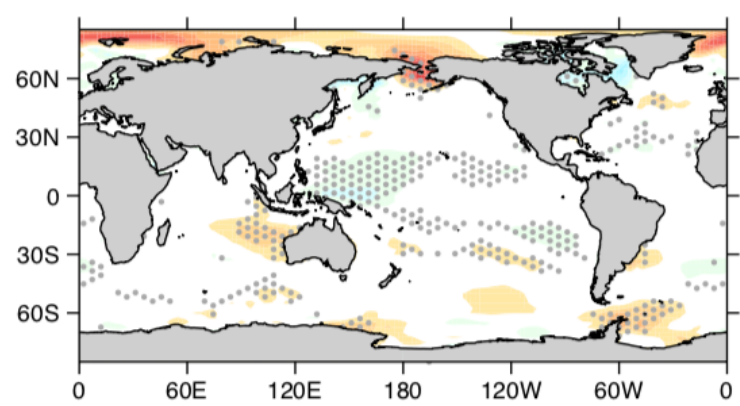

(d) PRCP [W3MMM]

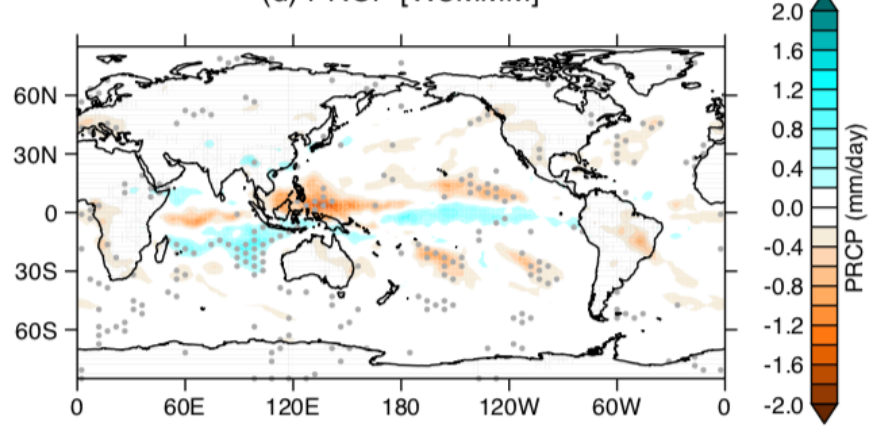

Supplementary Figure S8 | Global pattern of phase synchronized HC/WC shifts in CMIP5 models. Composite anomaly of PSYN months (i.e., the absolute tendency of phase difference is less than 0.3) with extreme SSTgrad greater than 1.5 standard deviation, for the S3MMM (left column) and W3MMM (right column) groups of the CMIP5 models: (a, b) SST (shading) and (c,d) precipitation anomalies. Stippling indicates areas where at least three models have a same signed response. 
(a) SST [S3MMM]

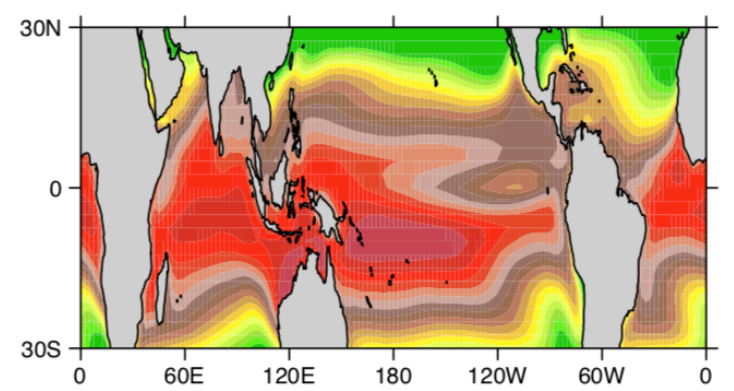

(c) U850 [S3MMM]

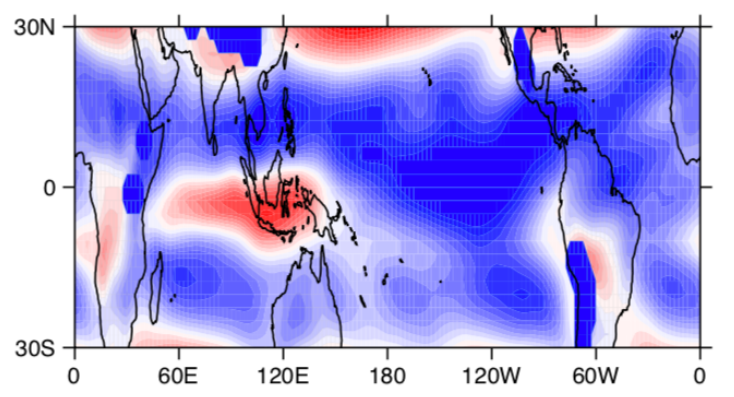

(b) SST [W3MMM]

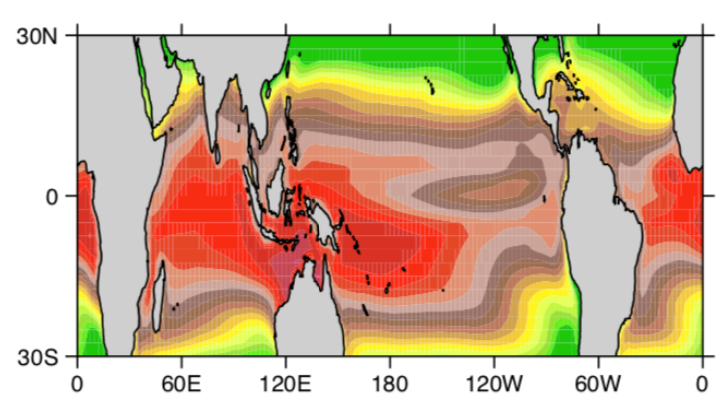

(d) U850 [W3MMM]

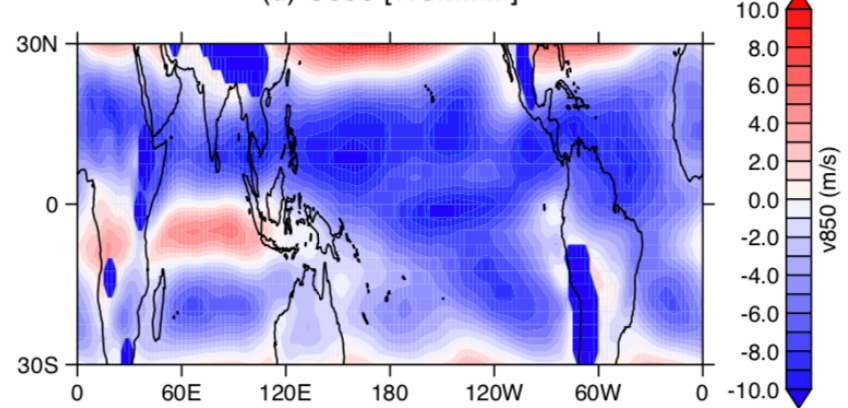

Supplementary Figure S9 | Climatological SST and zonal wind of the S3MMM and W3MMM model groups. Composite SST and $850 \mathrm{hPa}$ zonal wind climatology (1950-1999) for S3MMM and W3MMM. 
(a) SST/SF850 [OBS,WC2\&HC1>1SD]

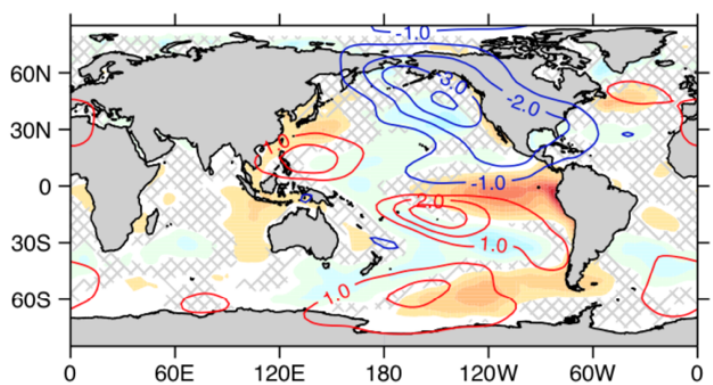

(c) VP850 [OBS,WC2\&HC1>1SD]

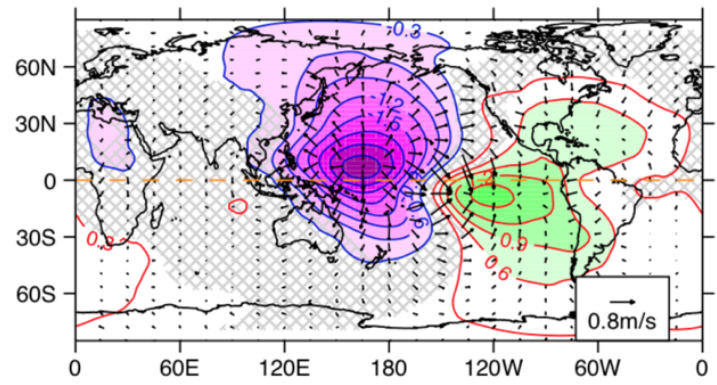

(e) PRCP/wind850 [OBS,WC2\&HC1>1SD]

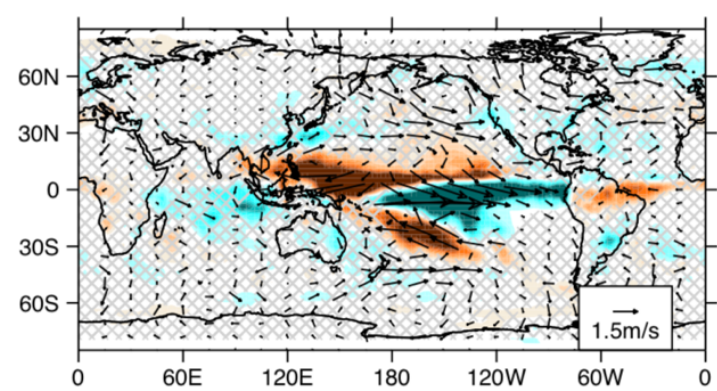

(b) SST/SF850 [OBS, WC2\&HC1<-1SD]

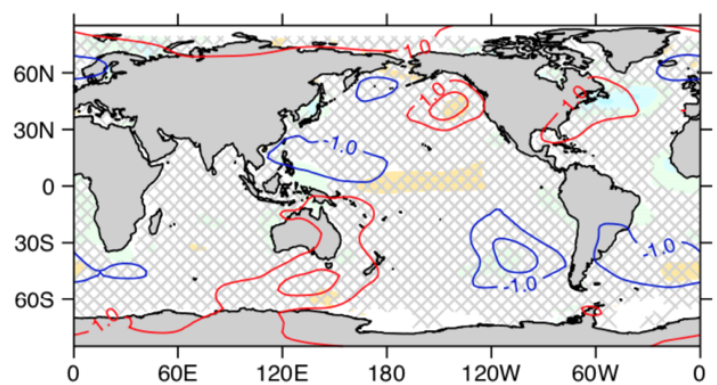

(d) VP850 [OBS,WC2\&HC1<-1SD]

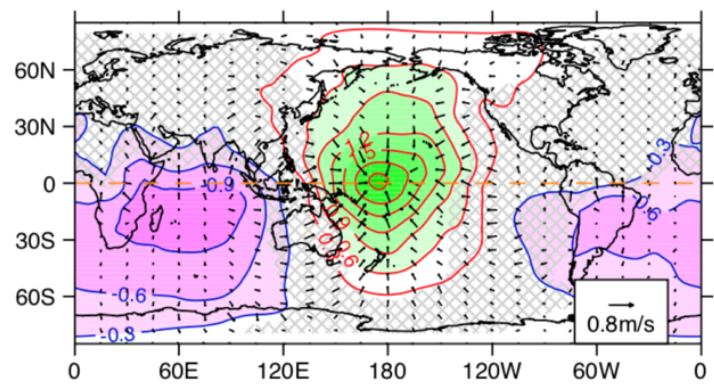

(f) PRCP/wind850 [OBS, WC2\&HC1<-1SD]

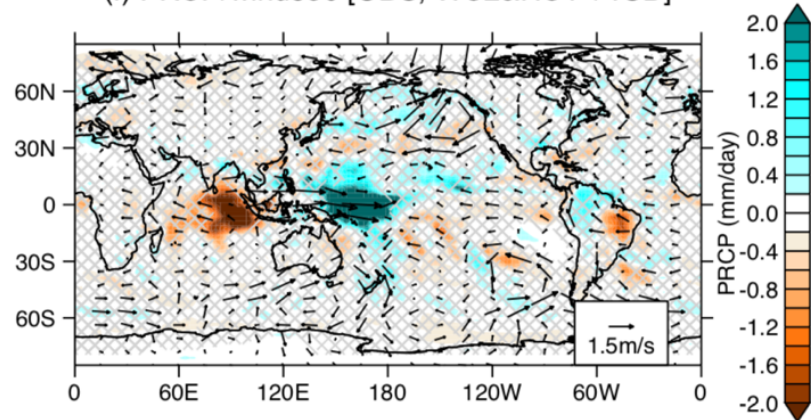

Supplementary Figure S10 | Asymmetry in the global pattern for the WC2-HC1 shift mode covariability. (a-b) Composite anomaly during WC2-HC1 co-varying months in (left column) positive (i.e., both $\mathrm{WC} 2$ and $\mathrm{HC} 1$ greater than 1.0 standard deviation) and (right column) negative (i.e., both WC2 and HC1 less than -1.0 standard deviation) cases, obtained from the observations: (a, b) SST (shading) and $850 \mathrm{hPa}$ stream function anomaly (contours); (c, d) VP850 anomaly; (e-f) GPCP precipitation (shading) and $850 \mathrm{hPa}$ wind (vectors) anomaly. Hatching indicates areas where the difference is statistically insignificant at the $95 \%$ confidence level. 
(a) SST/SF850 [OBS,WC1\&HC2>1SD]

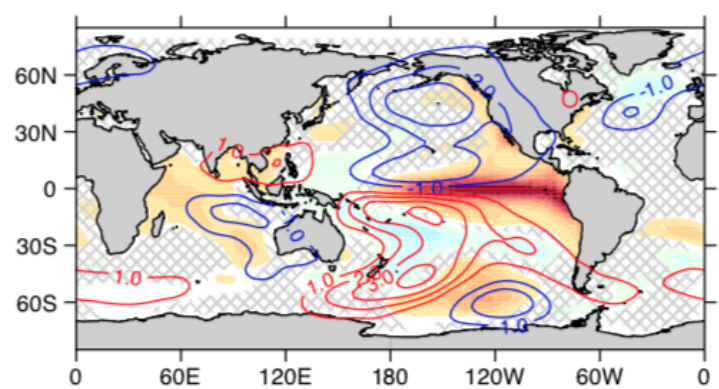

(c) VP850 [OBS,WC1\&HC2>1SD]

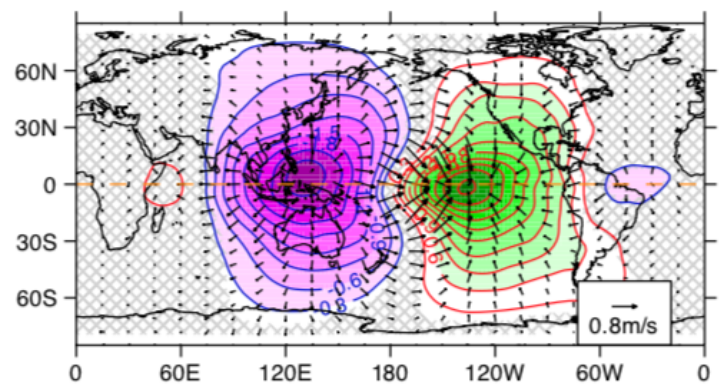

(e) PRCP/wind850 [OBS,WC1\&HC2>1SD]

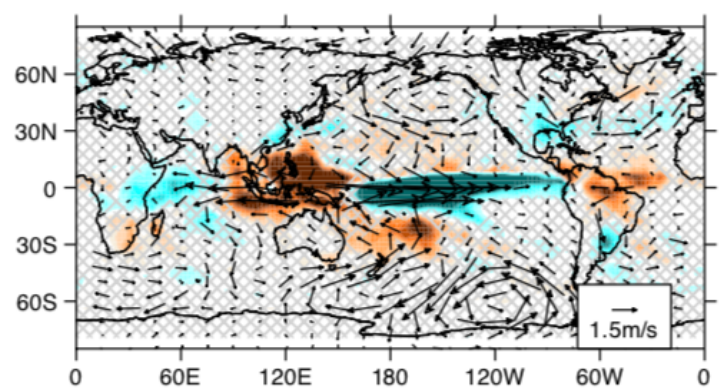

(b) SST/SF850 [OBS, WC1\&HC2<-1SD]

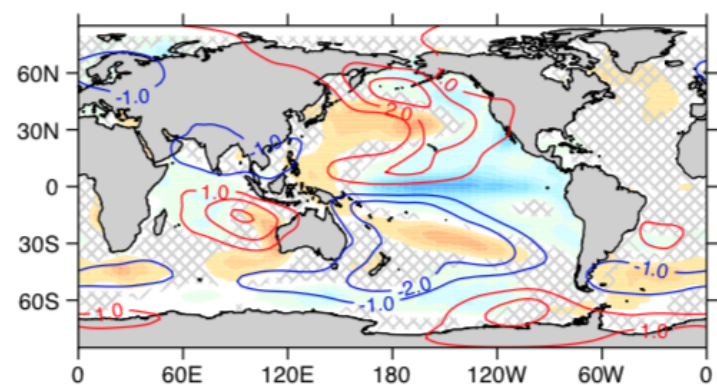

(d) VP850 [OBS,WC1\&HC2<-1SD]

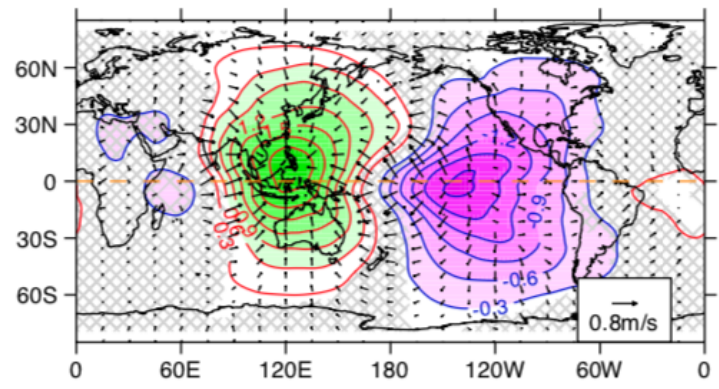

(f) PRCP/wind850 [OBS, WC1\&HC2<-1SD]

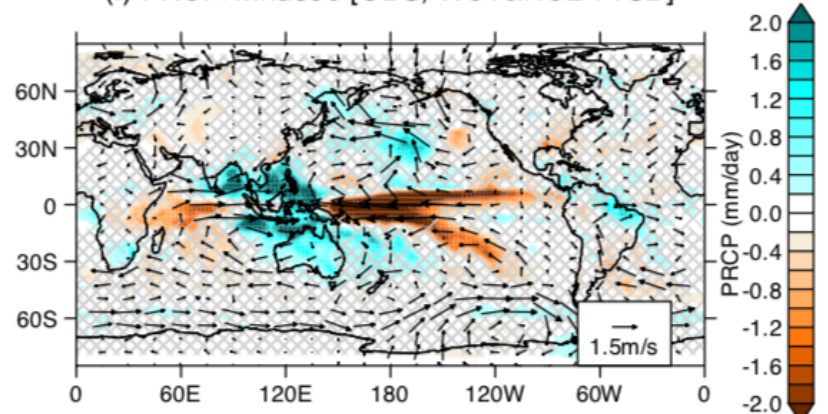

Supplementary Figure S11 | Symmetry in global pattern for WC1-HC2 strength mode covariability. (a-b) Composite anomaly during WC1-HC2 co-varying months in (left) positive (i.e., both WC1 and HC2 greater than 1.0SD) and (right) negative (i.e., both WC1 and HC2 less than 1.0SD) cases, obtained from the observations: (a, b) SST (shading) and $850 \mathrm{hPa}$ stream function anomaly (contours); (c, d) VP850 anomaly; (e-f) GPCP precipitation (shading) and 850hPa wind (vectors) anomaly. The hatching shows the area where the difference is insignificant at the $95 \%$ confidence level. 


\section{Supplementary References}

Bayr, T., D. Dommenget, T. Martin, and S. B. Power, 2014: The eastward shift of the Walker Circulation in response to global warming and its relationship to ENSO variability. Climate Dynamics, 43, 2747-2763. Ma, J., and J.-Y. Yu, 2014: Linking centennial surface warming patterns in the equatorial Pacific to the relative strengths of the Walker and Hadley circulations. Journal of the Atmospheric Sciences, 71, 34543464.

Oort, A. H., and J. J. Yienger, 1996: Observed interannual variability in the Hadley circulation and its connection to ENSO. Journal of Climate, 9, 2751-2767.

Xie, S.-P., and Z.-Q. Zhou, 2017: Seasonal modulations of El Niño-related atmospheric variability: Indowestern Pacific Ocean feedback. Journal of Climate, 30, 3461-3472. 